\title{
PERAN DAN KEDUDUKAN PEREMPUAN MANGKUNEGARAN DALAM SEJARAH PERKEMBANGAN KEBUDAYAAN JAWA MASA MANGKUNEGARA I-VIII
}

\author{
Dhian Lestari Hastuti ${ }^{11}$, Imam Santosa'), Achmad Syarief ${ }^{3)}$, dan Pribadi Widodo4) \\ 1, 2, 3,4) Program Studi Doktor Ilmu Seni Rupa dan Desain, Fakultas Seni Rupa dan Desain \\ Institut Teknologi Bandung \\ dhianlestarihastuti@students.itb.ac.id
}

\begin{abstract}
This research focuses on the role of Mangkunegaran women in the Mangkunegaran Kadipaten, so this study focuses on women's activities in the history of the Mangkunegaran Kadipaten until Indonesia's independence. The role of women (wives) in Javanese culture cannot be separated from the perspective of the paternalistic society as konco wingking. The understanding that man (Prophet Adam) was the first human and woman was created from his left rib. Left connotes something unimportant. Although this paternalistic perspective is inherent, no research has found a relationship between the policies of the Mangkunegaran kings and women as konco wingking. After understanding this position, so this research aims to reveal and understand this meaning in the policies of the Mangkunegaran kings. Based on the interaction analysis method of a qualitative approach with historical studies, this study collected informant insights and reference data through interviews, observation and document analysis. The results showed that the term konco wingking for Mangkunegaran kings was more appropriate with the term "garwo or sigaraning nyowo", because the struggles and policies of the kings of Mangkunegaran involved women as a form of adaptive cultural system implementation, both in the domestic sphere and in formal education and even as a form cultural diplomacy.
\end{abstract}

Keywords: Duchy of Mangkunegaran, king's policy, the role of women, cultural system

\section{PENDAHULUAN}

\section{Latar Belakang}

Budaya Jawa mengenal pembagian peran terhadap laki-laki dan perempuan yang dipengaruhi oleh konsep paternalistik. Selama ini konsep tersebut yang diketahui masyarakat umum. Di antara konsep tersebut adalah memposisikan perempuan dengan istilah sebagai konco wingking. Laki-laki dianggap sebagai manusia pertama yang hadir di dunia dan perempuan tercipta setelahnya dan berasal dari tulang rusuknya yang sisi kiri. Lahir setelah laki-laki dan berasal dari tulang rusuk kiri, terkesan bahwa perempuan menjadi sesuatu yang tidak penting. Terlebih dengan istilah konco wingking yang diartikan bahwa perempuan khususnya istri, hanya diposisikan sebagai subordinat dan bertanggung jawab di wilayah domestik di seputar kasur (tempat tidur), dapur, dan sumur. Tiga tempat tersebut sebagai area khusus bagi perempuan ketika sudah menikah. Tanggung jawab terhadap tiga area tersebut bagi perempuan dalam bentuk kata kerja aktif adalah mereka memiliki kewajiban untuk masak (memasak), macak (berhias), manak (melahirkan). Sekilas terkesan dangkal dan perempuan hanya sebagai properti dan objek, bukan subjek. Namun di sisi lain ada istilah garwo atau sigaraning nyowo atau belahan jiwa dalam bahasa Indonesia. Garwo lebih terkesan sejajar sebagai dua yang menjadi satu. Istri menjadi separo entitas yang satu dari suami istri (Handayani dan Novianto, 2004: 120).

Budaya Jawa memiliki prinsip-prinsip dalam etika berelasi dengan orang lain, yang menuntut setiap pribadi untuk mawas diri. Salah satu ungkapan tersebut adalah empan papan yang bermakna positif (Endraswara, 2016: 5). Sebaiknya individu mampu menempatkan diri dalam situasi dan kondisi di manapun tempatnya, agar tetap terawat keselarasan relasi sosialnya. Ungkapan atau pepatah lain yang menjadi jati diri orang atau masyarakat Jawa adalah sadumuk bathuk sanyari bumi ditohi pati (Endraswara, 
2016: 3). Pepatah ini berarti satu sentuhan pada dahi dan satu pengurangan ukuran atas tanah (bumi) selebar jari bisa dibayar atau dibela dengan nyawa (pati). Makna dari pepatah tersebut, sedemikian tinggi harga diri orang Jawa, sehingga menghargai diri orang lain sama besarnya dengan menghargai diri sendiri. Demikian halnya dalam relasi kepemilikan sah seseorang atas pasangan, istri atau suami pantang untuk disentuh orang lain, yang dapat terwakili dengan kata sadumuk bathuk. Hal tersebut tidak dalam makna harfiah atau fisik, namun lebih pada harga diri atau kehormatan.

Dua kaidah dasar kehidupan masyarakat Jawa dalam menjaga keselarasan adalah prinsip rukun dan hormat, di samping kesadaran dan kewaspadaan dalam menempatkan diri dan harga diri, (Suseno, 1996: 39-81). Prinsip rukun adalah hal yang utama dengan tidak mengambil posisi yang mengakibatkan konflik, sedangkan prinsip hormat adalah cara bersikap dan berkomunikasi dengan memahami kedudukan dan posisi dalam struktur sosial, sehingga setiap individu dapat mengendalikan diri untuk menjaga keselarasan relasi sosial. Muara ungkapan-ungkapan dalam relasi sosial masyarakat Jawa, baik empan papan maupun sadumuk bathuk sanyari bumi ditohi pati adalah prinsip rukun dan hormat tersebut. Semuanya tidak hanya menjadi ungkapan fisik saja, namun melibatkan sikap batin setiap pribadi manusia Jawa.

Kehidupan masyarakat Jawa tidak lepas dari peran para raja, karena raja dipercaya sebagai sumber kekuatan kosmis yang mengalir dan membawa ketentraman, keadilan dan kesuburan. Raja yang bertempat atau bersemayam bukan saja sebagai pusat politik dan budaya namun juga sebagai area sakral kerajaan. Akibat perjanjian Giyanti dan Salatiga menjadikan kerajaan Mataram terbagi menjadi empat kerajaan dengan wilayah kekuasaan masing-masing. Kerajaan di wilayah Surakarta terdiri atas Kasunanan Surakarta dengan nama penguasa Paku Buwana yang berarti paku jagad raya, sedangkan Kadipaten Mangkunegara dengan nama penguasa Mangkunegara berarti yang memangku negara. Gelar bagi raja Mangkunegara adalah Kanjeng Gusti Pangeran Adipati Arya (KGPAA) Mangkunegara, adipati sebagai gelar raja muda atau dimaknai sebagai wakil raja. Penguasa Mangkunegaran adalah pengusa setingkat kadipaten, sehingga gelar yang disandang rajanya adalah adipati.

Keberadaan raja-raja Jawa tidak lepas dari relasi atau peran para perempuan di sekelilingnya, baik secara imajiner maupun nyata dalam berkehidupan. Berlangsungnya pemerintahan atau kekuasaan tidak lepas dari kepercayaan masyarakat Jawa, bahwa sumber langgengnya kepemimpinan raja dan kemakmuran wilayahnya dipengaruhi oleh relasi tersebut. Tokoh imajiner perempuan dalam budaya Jawa dikenal sebagai pemberi kesuburan dan kemakmuran adalah Dewi Sri, sedangkan penguasa sumbu kosmis selatan Nyai Roro Kidul adalah Dewa Anantaboga bermakna memberi kesabaran dan kasih (Frick, 1997: 85). Selain tokoh perempuan imajiner tersebut raja-raja Jawa hidup dengan sistem perkawinan poligami, tidak hanya istri utama sebagai permaisuri, bahkan memiliki permaisuri lebih dari satu dan banyak selir (Soeratman, 1989: 50).

Keberadaan para perempuan raja-raja Mangkunegaran dikenal memiliki peran pada masa perjuangan dan selama pemerintahan Kadipaten Mangkunegaran, bahkan hingga kadipaten ini menyatakan diri menjadi bagian dari pemerintah Republik Indonesia. Bagaimana raja-raja Mangkunegaran sebagai pemegang kekuasaan setingkat kadipaten memposisikan dan memberikan peran para perempuan dalam sejarah berdirinya Kadipaten Mangkunegara dan dalam pengembangan budaya Jawa. Bagaimana raja-raja Mangkunegaran menempatkan para perempuannya di masa pemerintahannya, hingga prinsip rukun dan hormat dapat terjaga hingga relasi sosial di dalam lingkungan Pura Mangkunegaran menjadi selaras dan harmoni.

Objek penelitian ini adalah serat atau naskah, dan dokumen yang berkaitan dengan posisi dan peran para perempuan dalam budaya Jawa di perpustakaan Reksapustaka Pura Mangkunegaran. Penelitian ini merupakan penelitian kualitatif dengan metode interaksi analisis dengan studi sejarah, penelitian ini mengumpulkan wawasan informan dan data referensi melalui wawancara, observasi dan analisis dokumen. 
Keberadaan perempuan dalam budaya Jawa mengungkap kesejatian kedudukannya dalam sistem sosial masyarakatnya. Begitu juga dalam sistem sosial masyarakat Kadipaten Mangkunegaran, perempuan menjadi bagian dari kepentingan raja dalam berinteraksi membentuk identitas sosialnya dengan penguasa swapraja lainnya dan pemerintah kolonial. Dalam tiga wujud kebudayaan menurut Koentjaraningrat (181-185, 224), yaitu: (a) kebudayaan yang berwujud gagasan, ide, norma atau peraturan; (b) kebudayaan yang berwujud aktivitas kompleks dan tindakan berpola manusia dalam masyarakat; (c) kebudyaan sebagai benda hasil karya manusia. J.J Honigmann menyebutnya dengan tiga gejala kebudayaan, yaitu ideas, activities, dan artifact.

Berdasarkan referensi tersebut maka, penelitian ini fokus pada activities atau sistem sosial masyarakat Mangkunegaran yang diungkap dan dipahami melalui penelitian deskriptif kualitatif dengan metode interaksi analisis. Harapannya dengan penelitian ini, peneliti dapat memberikan kontribusi terhadap pemahaman makna perempuan bagi raja-raja Mangkunegaran dalam menjaga dan merawat relasi sosial, baik secara pribadi maupun sebagai simbol pusat kekuatan kosmis Kadipaten Mangkunegaran serta dalam sejarah perkembangan kebudayaan Jawa.

\section{Tujuan}

Penelitian ini bertujuan untuk memahami makna para perempuan Mangkunegaran melalui posisi dan peran mereka pada masa kepemimpinan Mangkunegara I-VIII dan masa pemerintahan Republik Indonesia.

\section{Metode Penelitian}

Penelitian ini menggunakan metode pendekatan kualitatif dengan studi sejarah, mengumpulkan wawasan informan dan data referensi melalui wawancara, observasi dan analisis dokumen. Peran perempuan terhadap raja-raja dan pemerintahan Kadipaten Mangkunegaran dieksplorasi, sehingga menempatkan Pura Mangkunegaran sebagai latar budaya tempat penelitian dengan alasan sebagai berikut. (a) Pura Mangkunegaran sebagai pusat sistem budaya dan sosial kadipaten dengan latar budaya Jawa sebagai dasar filosofi dan falsafah dalam berkehidupan.

(b) Pura Mangkunegaran sebagai tempat implementasi segala kebijakan raja, yang berlaku bagi para perempuan Jawa yang berada di lingkungan pusat pemerintahan yang setingkat kadipaten.

Penelitian dilakukan dalam dua tahap, yaitu:

(a) Tahap deskripsi tentang posisi perempuan (khususnya istri) di dalam beberapa Serat (Naskah atau Sastra Jawa) dan dalam ungkapan sebagai konco wingking diperbandingkan dengan posisi sebagai garwo atau sigaraning nyowo.

(b) Tahap studi sejarah dengan tahapan 1) heuristik, peneliti melakukan studi dokumen dan arsip tentang kepemimpinan Mangkunegara I-VII terkait dengan perempuan di Rekso Pustaka Mangkunegaran dan wawancara sejarawan. 2) kritik sumber atau verifikasi, tahapan peneliti menentukan keakuratan data. 3) tahap interpretasi, peneliti merangkaikan beberapa fakta derdasarkan data sejarah dengan dilandasi ilmu, agar mendapatkan landasan pemikiran, sehingga mendapatkan interpretasi yang tepat. Tahap intepretasi ini tentang kebijakan raja-raja Mangkunegaran dan implementasinya terhadap peran perempuan (istri) Mangkunegaran. 4) Tahapan historiografi, yaitu tahapan peneliti melakukan penulisan sejarah tentang jejak perempuan Mangkunegaran sesuai dengan sistematis dan kronologis ssesuai kekuasaan Adipati Mangkunegara dan riwayat kepemimpinan pemerintah Indonesia.

\section{Kajian Pustaka}

\section{a. Perempuan dalam Budaya Jawa}

Perempuan dalam posisi sebagai istri atau ibu dalam budaya Jawa memiliki nilai kearifan yang terungkap melalui beberapa serat dalam Sastra Jawa. Di antara serat tersebut adalah Serat Wulangreh, Serat Wulang Estri, Serat Candrarini, Serat Yadya Susila, Serat Wulang Jayalengkara, dan Serat Centhini. Hasil studi 
pustaka dan wawancara dengan R. Ngt. Ng. Dra Darweni (30 September 2020) sebagai pengelola buku dan manuscript perpustakaan Reksapustaka (penerjemah Bahasa Jawa) masing-masing serat memberikan ajaran dan pesan yang berbeda.

Serat Wulangreh memberikan nilai kearifan tentang dunia batiniah sebagai pangkal atau dasar berpijak bagi etika dan ajaran moral bagi manusia. Serat Wulang Estri memberikan nilai kearifan tentang kewajiban bersyukur bagi manusia, baik laki-laki maupun perempuan, kepada Tuhan yang telah menciptakannya sebagai manusia bukan binatang. Serat Candrarini memberikan nilai kearifan tentang perempuan beriman yang terus menerus berdoa untuk mendapatkan wahyu dan anugerah dari Tuhan Yang Maha Esa dan perempuan ini termasuk yang berbudi luhur. Di sisi lain serat ini juga menceriterakan tentang lima karakter perempuan istri tokoh Arjuna dalam wayang, yaitu: Sembodro, Dewi Manohara, Dewi Hulupi, Retno Gondowati, dan Srikandi. Kelimanya berbeda-beda, masing-masing punya kelebihan, saling melengkapi, dan saling ngemong (mengasuh). Serat Yadya Susila memberikan nilai tentang perempuan yang berbudi luhur adalah perempuan yang mempunyai sikap luluh, luwes, adaptif, dan mengalir. Serat Wulang Jaya Lengkara memberikan nilai tentang pemimpin yang baik adalah yang memiliki watak "wong catur". Watak wong catur tersebut adalah retna atau permata watak pengayom dan pengayem seorang pemimpin adalah (1) memberikan ketentraman dan perlindungan diri, (2) watak estri atau perempuan berbudi luhur, bersifat sabar, bersikap santun dan mengalahkan tanpa kekerasan, (3) watak curiga atau keris, memiliki ketajaman dalam berolah pikir untuk menentukan kebijakan, (4) watak paksi atau burung yang mampu terbang lepas ke manapun berwawasan luas dan independen. Serat Centhini memberikan nilai tentang perempuan yang gemi (hemat), wedi (takut), dan bekti ing laki (berbakti pada suami).

Kelima serat tersebut masing-masing memberikan nilai bagi perempuan bagaimana berkehidupan dalam budaya Jawa. Kehidupan batin bagi manusia Jawa menjadi pusat dari pengendali hidupnya, dengan dilingkupi rasa syukur kepada Tuhan dan tetap beriman dan berdoa agar mendapatkan anugerahNya menjadi tugas perempuan yang berbudi luhur. Sikap luwes dan adaptif serta watak wong catur bagi seorang pemimpin adalah watak yang dimiliki seorang perempuan. Serat Centhini khusus memberikan nilai bagaimana sikap seorang perempuan yang sudah berkeluarga dalam berelasi dengan suami dan anak.

\section{b. Mangkunegaran dalam Catatan Rinkes dan Metz}

Catatan Rinkes 4 September 1924 yang diterjemahkan RM. Sarwanta pada tahun 1978 (MN. 142) memberikan informasi tentang karakter kepemimpinan raja-raja Mangkunegaran dibanding ketiga kerajaan yang lain, Kasunanan Surakarta, Kasultanan Yogyakarta, dan Pura Pakualaman. Dalam catatan tersebut Mangkunegaran memiliki tradisi yang demokratis dan sikapnya Jawa istimewa, artinya menjunjung apa yang hidup dalam hati rakyat Jawa dan menunjukkan jalan bagaimana dapat hidup bersama dengan kemajuan dunia tanpa kehilangan sifat yang telah dimiliki. Mangkunegaran berkarakter nasionalis dan modern.

Catatan lain ditulis oleh Dr. Th. M. Metz sebagai sekretaris Kamar Dagang Belanda untuk Jerman di Kota Gravenhage dengan judul Mangkunegaran: Analisis Sebuah Kerajaan Jawa, dalam bahasa Jerman diterbitkan pada atahun 1934. Catatan tersebut kemudian diterjemahkan oleh R. Tg. Muhammad Husodo Pringgokusumo yang bertugas sebagai Kepala Kantor Reksopustoko pada tahun 1987. Catatan ini lebih menuliskan kebijakan pada masa pemerintahan Mangkunegara VII, yang terlibat aktif dalam perkumpulan Budi Utomo yang bertujuan mempertinggi kebudayaan Jawa melalui sistem pengajaran (1987: 86). Penyelenggaraan Konggres Kebudayaan, 5-6 Juni 1918 dengan melibatkan pembicara dari orangorang Eropa, hingga pada tanggal 4 Agustus 1919 lahir Java Institut di Yogyakarta dan Mangkunegara VII sebagai Ketua Kehormatan. Java Institut berperan dalam studi Kebudayaan Jawa dan memperluasnya ke dunia agar lebih terkenal. Pendirian Solosche Radio-omroep Vereniging (SRV) sekarang RRI Surakarta 
untuk menyiarkan Kebudayaan Jawa. Sekolah desa sebanyak 19 tersebar di wilayah praja Kadipaten Mangkunegaran dan berkembang, sampai pemberian beasiswa kepada mereka yang kurang mampu.

Inisiasi membentuk hubungan kerjasama dengan Bali yang kebudayaannya sama asal-usulnya dengan Kebudayaan Jawa, bahkan Mangkunegaran terbuka bagi pengaruh dari semua negara dan peradaban di dunia. Metz hingga menuliskan kebangkitan seorang pemimpin dari peradaban rohani di pulau Jawa, seorang pemimpin yang juga seorang raja, seniman, ilmuwan yang berperasaan halus, dan berbakat memimpin rakyatnya ke arah perkembangan rohani. Hal tersebut mustahil tercapai bagi seorang pemimpin yang kekurangan energi (1987: 92)

Sumber literatur tersebut memberikan arah penelitian tentang sikap hidup perempuan Jawa dan raja-raja Mangkunegaran. Catatan Dr. Th. M. Metz memberikan wawasan bagi peneliti sikap dan peran Mangkunegara VII pada masa pemerintahannya terhadap upaya membangun kebangsaan menuju Indonesia merdeka. Kontribusinya sebagai pemimpin yang terbuka dan membangun peradaban pada masanya. Korelasi antara peran dan perempuan dengan raja-raja menjadi bagian sistem sosial Kadipaten Mangkunegaran, yang membentuk dan mengembangkan budaya "Jawa Mangkunegaran".

\section{PEMBAHASAN}

\section{Istilah dan Padanan Kata Perempuan dalam Budaya Jawa}

Budaya Jawa mengenal berbagai istilah dalam menyebut perempuan. Masing-masing istilah merujuk kepada peran perempuan dalam kehidupan sehari-hari. Istilah yang dimaksud dalam makna sebagai perempuan yang sudah menikah, karena ada sebutan tersendiri bagi perempuan yang belum menikah. Sesuai dengan hasil wawancara dengan R. Ngt. Ng. Dra Darweni: Pengelola buku dan manuscript perpustakaan Reksapustaka sebagai penerjemah Bahasa Jawa, pada 5 Oktober 2020, berikut beberapa makna dari kata perempuan dan beberapa kata padanannya.

Perempuan berasal dari bahasa Sansekerta, yang muncul dari per + empu + an. Per bermakna makhluk, sedangkan empu bermakna mahir, mulia, atau tuan. Imbuhan an dalam bahasa Jawa merujuk kata benda, kata kerja, atau kata tempat. Maka kata perempuan dapat dimaknai sebagai makhluk yang mulia atau yang berkemampuan.

Padanan kata perempuan dalam bahasa Jawa adalah wadon, wanitå (baca wanito), estri, dan putri. Wadon berasal dari kata wadu dalam bahasa Kawi. Kata tersebut secara harfiah berarti kawula atau abdi. Perempuan dengan kata wadon, memiliki takdir atau titah selama hidup didunia sebagai abdi (pelayan) dan bekti ing laki (berbakti pada suami). Wanitå merupakan dua gabungan kata wani (berani) dan tåtå (atur) atau wani (berani) dan nåtå (mengatur). Dua gabungan kata wani (berani) dan tåtå (atur) bermakna, bahwa wanitå berani atau mau diatur, yang bermakna bahwa seorang perempuan wajib tunduk dan patuh terhadap suami, sedangkan wani dan nåtå bermakna perempuan harus berani atau mau mengatur, yang bermakna mampu untuk mengatur dan mengelola segala sesuatu yang berkaitan dengan hidup berumah tangga, hingga kesantunan, kebahagiaan, dan kesejahteraan keluarga tercapai. Estri berasal dari kata estren dalam bahasa Kawi, yanag bermakna penjurung atau pendorong. Dalam bahasa Jawa ada istilah hangestreni yang bermakna mendorong, sehingga mengandung makna tanggung jawab bahwa sebagai estri wajib mendorong suami dalam memberikan dukungan dan semangat serta pertimbangan. Putri berarti anak perempuan. Dalam budaya Jawa, kata putri merupakan akronim dari putus tri perkawis. Kata putri bermakna, sebagai perempuan harus mewujudkan tri perkawis atau tiga perkara yaitu berperan sebagai wadon, wanitå, dan estri.

Peristilahan tersebut dapat ditemui dalam naskah-naskah atau serat yang berwujud tembang, sehingga penempatan dan penggunaan kata wadon, wanitå, dan estri disesuaikan dengan rima atau guru lagu dalam tembang tersebut, sehingga ketika dilantunkan dalam tembang pengucapan dan pesannya sesuai 
dengan makna yang diharapkan.

Perempuan menjadi bagian dari kata omah, yang merupakan gabungan dua kata "om" mewakili langit atau angkasa dan " $m a h$ " mewakili bumi, sehingga muncul istilah Bapak angkasa dan ibu bumi. Omah adalah simbolisasi bagi tempat bernaung sebagai jagad gedhe (makrokosmos) bagi manusia Jawa yang berposisi sebagai jagad cilik (mikrokosmos). Selain itu omah menjadi simbolisasi sinergisitas dalam membentuk keselarasan dari dua karakter yang berbeda, laki-laki dan perempuan sehingga tercapai harmoni dalam hidup.

Perempuan sebagai ibu bumi dalam budaya Jawa hadir dalam simbolisasi Dewi Sri atau dewi padi sebagai sumber kehidupan masyarakat agraris. Perempuan dalam budaya Jawa hadir sebagai subjek yang mengada, dengan kata lain melahirkan keturunan untuk generasi penerus dan pembentuk peradaban. Menurut KGPH Dipokusumo (dalam wawancara, 4 November 2020), perempuan itu disebut nareswari artinya perempuan itu sebagai manusia yang dipilih dan dipercaya Tuhan untuk melahirkan keturunan, sehingga masyarakat Jawa mensyaratkan bobot, bébéd, bibit bagi perempuan yang akan diperistri. Bobot merujuk pada kualitas diri terkait dengan lengkapnya fisik, inner beauty (termasuk agama), memiliki tata krama, dan wasis atau ulet dan rajin. Bébéd sebagai simbol status sosial atau harkat dan martabat. Bibit bermakna asal usul atau garis keturunan harus jelas, terkait dengan watak dan karakter yang diturunkan.

Nareswari merupakan istilah untuk perempuan terkait dengan kodratnya yang melekat dalam hidup dan tidak bisa dialihkan kepada laki-laki, yaitu mengandung, melahirkan, dan menyusui. Kodrat tersebut dalam istilah perempuan sebagai konco wingking merupakan penjelasan makna kata manak. Manak tidak dengan makna sempit atau negatif, namun justru perempuan sebagai inti dari pembentuk peradaban. Perempuan dengan kodrat tersebut dimaknai sebagai manusia yang dipercaya Tuhan untuk selalu berbagi dan memberi dengan apa yang dimiliki selama hidupnya. Kepekaan dan kepedulian dimiliki perempuan karena selalu berbagi dan memberi. Sesuai dengan makna kata perempuan, sebagai makhluk yang mulia dan berkemampuan untuk melahirkan penerus keturunan, dari sesuatu yang tidak ada menjadi ada karena kuasa Tuhan.

\section{Prinsip Rukun dan Hormat Perempuan Jawa dalam Serat.}

Prinsip rukun adalah salah satu dari kaidah hidup berelasi masyarakat Jawa. Jika mampu hidup rukun maka kehidupan akan selaras dan harmoni. Kata rukun bermakna bahwa manusia sebagai pribadi tidak bermakna, jika tidak menjadi bagian dari manusia yang lain, ada kebutuhan berelasi dengan yang lain. Begitu juga dengan manusia Jawa yang sesuai dengan ungkapan "rukun agawe santosa" artinya rukun membawa ketentraman, berusaha tidak menimbulkan konflik sehingga relasi menjadi tidak selaras, sehingga "crah agawe bubrah" artinya pertengkaran atau perselisihan yang berakibat (membuat) kerusakan.

Relasi idea berpikir masyarakat Jawa dalam kosmologinya selalu menjaga keselarasan antara jagad gedhe (makrokosmos) dan jagad cilik (mikrokosmos). Semesta alam adalah jagad gedhe, lingkungan tempat manusia Jawa tinggal adalah jagad cilik. Lingkungan adalah jagad gedhe dan rumah tempat manusia Jawa bernaung adalah jagad cilik. Rumah sebagai jagad gedhe dan manusia yang bernaung adalah jagad cilik. Raga atau fisik manusia adalah jagad gedhe dan jiwa manusia adalah jagad cilik. Semesta alam dan jiwa manusia Jawa saling berelasi, bahwa jiwa yang memberikan 'warna' bagi setiap pribadi hingga saling berelasi dan mampu mempengaruhi cara pandang serta sikapnya terhadap semesta alam sebagai ciptaan Tuhan. Relasi antara sesama manusia, alam, dan Tuhan yang selaras dan harmoni bergantung pada sikap batin setiap individu manusia Jawa.

Sikap batin sebagai dasar berpijak dalam beretika dan ajaran moralnya untuk setiap pribadi Jawa yang berusaha mengendalikan diri. Hal tersebut seperti yang terkandung dalam Serat Wulangreh, bahwa dunia batiniah menjadi dasar berpijak manusia Jawa dalam berkehidupan. Seperti halnya dalam konsep moncopat yaitu keblat papat kalimo pancer dalam kosmogoni Jawa. Empat nafsu yaitu: lau- 
wamah (serakah), amarah (angkara murka), supiah (birahi), mutmainah (jujur), dan sifat kama (budi) sebagai subyek nafsu batin manusia (Dharsono, 2007: 121-122). Kama (budi) baik setiap pribadi manusia Jawa tergantung pada kemampuan diri dalam mengendalikan empat nafsu tersebut, bahwa sebenarnya masalah tidak timbul dari orang lain, tetapi timbul dari diri sendiri, karena ketidakmampuan mengendalikan empat nafsu tersebut. Kecerdasan dalam membentuk sikap batin yang baik membawa kerukunan dalam berkehidupan, baik dengan keluarga maupun masyarakat, tidak terkecuali bagi laki-laki maupun perempuan.

Serat Candrarini mengajarkan perempuan untuk menjaga dan merawat relasi dengan Tuhan agar harmoni dan mendapatkan anugerah melalui keimanan dan doa-doa yang terus menerus dipanjatkannya. Prinsip kerukunan dari serat tersebut juga digambarkan melalui perbedaan watak dan karakter kelima istri tokoh Arjuna yang saling melengkapi. Serat Candrarini menggambarkan figur wanita yang baik melalui para kelima istri Arjuna.

Watak dan karakter kelima istri Arjuna tersebut, sebagai berikut. Sumbodro sebagai istri pertama memegang peranan penting dengan kerelaannya untuk dimadu dan memegang kendali dalam "ngemong" keempat istri Arjuna yang lain. Sumbodro sebagai figur putri yang sederhana, selalu ceria, sangat pemaaf dan setia kepada suami, bahkan terhadap madu pun dianggapnya sebagai saudara yang mengabdi kepada suami. Dewi Manuhara sebagai figur perempuan yang santun, perkataannya halus, dan menyenangkan, bersikap baik terhadap madunya dan tidak angkuh serta dapat melihat situasi, peka (tanggap ing sasmita). Dewi Ulupi sebagai figur perempuan yang menarik hati berwajah ceria, luwes dalam berbicara, menjaga kasih sayang terhadap suami dan madunya, dan siap dengan segala kebutuhan suami. Dalam bersikap selalu waspada, sehingga disegani oleh rakyat. Retna Gandawati adalah sebagai figur perempuan yang berwibawa, bersikap tenang, halus berbicaranya, teliti dalam kerja dan bertindak, santun terhadap suami, akrab dan menganggap saudara kepada para madunya dan seslau siap dengan apa yang harus dikerjakan perempuan. Wara Srikandi merupakan figur perempuan yang cekatan, lantang berbicara tetapi luwes dalam penampilan, sealalu sigap melaksanakan perintah suami, selalu bersikap ramah terhadap para madunya, dan terhadap mertua selalu santun, berbakti, sayang serta selalu menyiapkan kesukaan mertuanya setiap hari.

Peranan Sumbodro terhadap para madunya mempengaruhi relasi kelimanya untuk bersikap lembut, luluh, adaptif, dan mengalir dengan situasi dan kondisi yang terjadi seperti pada nilai kearifan Serat Yadya Susila dan watak "wong catur" dalam Serat Wulang Jaya Lengkara. Maka karakter dari kelima istri Arjuna tersebut dapat sebagai contoh pelaksanaan prinsip hormat dan rukun dalam masyarakat Jawa. Prinsip hormat wajib bagi laki-laki maupun perempuan, seperti dalam ungkapan empan papan dan sadumuk bathuk sanyari bumi ditohi pati. Menempatkan orang lain sehormat-hormatnya dan memperlakukan orang lain seperti diri sendiri, sehingga tercapai prinsip rukun.

\section{Posisi Perempuan dalam Naskah (Serat) Jawa}

Perempuan Jawa adalah perempuan yang berbahasa Jawa, yang masih berakar dalam kebudayaan dan cara berpikir sebagaimana yang terdapat dalam budaya Jawa. Maka definisi atau maksud dari pribadi perempuan Jawa adalah mereka dengan keseluruhan sikap dan watak perempuan yang berbahasa dan berakar budaya Jawa. (Soedarsono dan Murniatmo, 1986: 3). Pengertian bagaimana perempuan Jawa dalam bersikap terdapat dalam beberapa serat atau naskah Jawa terkait dengan perempuan. Begitu juga dengan pengertian dan makna konco wingking dan garwo atau sigaraning nyowo dalam budaya Jawa dapat dipahami lebih dengan mengkaji perempuan dalam beberapa serat atau naskah Jawa dan dalam keseharian masyarakat Jawa.

Perempuan sebagai konco wingking dan garwo atau sigaraning nyowo diperuntukkan bagi perempuan Jawa yang sudah menikah. Serat Wulangreh, Serat Wulang Estri, Serat Candrarini, Serat Yadya Susila, Serat Wulang Jayalengkara, dan Serat Centhini adalah naskah yang mengandung edukasi bagi perem- 
puan dalam kehidupan berumah tangga dan bagaimana bersikap sebaik-baiknya terhadap suami. Sesuai dengan kajian literatur terhadap beberapa serat atau naskah tersebut, maka perempuan menjadi bagian dari pribadi yang mempunyai sikap batin dan selalu mengendalikan serta mengkontrol diri. Hal tersebut dilakukan sebagai upaya untuk menjalankan prinsip rukun dan hormat. Perempuan dituntut untuk adaptif dengan situasi apapun, kepekaan dan tanggap terhadap bahasa nonverbal yang terjadi di sekitarnya. Prinsip tersebut tidak hanya dalam berinteraksi sosial, tetapi juga dalam relasi suami dan istri. Seperti yang diajarkan dalam naskah atau Serat Yadya Susila, bahwa perempuan dituntut untuk berbudi luhur, luwes dan adaptif.

Serat atau naskah tentang perempuan isinya hampir sama memberikan arahan atau semacam edukasi bagi perempuan Jawa dalam berperilaku dan bersikap tehadap suami. Perempuan sebagai ibu dalam keluarga Jawa merupakan pengendali keluarga baik bagi suami atau anak. Perempuan sebagai wanitå, pribadi yang wani nåtå berani mengatur segala sesuatu yang berkaitan dengan martabat keluarga, hingga pilihan pasangan (suami atau istri) bagi anak-anaknya. Bahkan jika musibah atau kesulitan yang melanda keluarga, perempuan sebagai istri sekaligus ibu harus berani mengambil sikap, tanggap dengan situasi dan kondisi untuk berjuang mempertahankan keutuhan keluarga.

Laki-laki sebagai suami menjadi pribadi yang hadir di ranah publik dan perempuan Jawa dengan kesadaran dirinya tidak akan mengambil peran dalam otoritas tersebut. Perempuan Jawa diajarkan untuk tidak memiliki kehendak dan otoritas pribadi, namun dia sebagai penentu dalam pola relasi suami istri agar tetap terawat, selaras, dan harmoni. Melayani dan mengabdi kepada suami merupakan bentuk positioning perempuan Jawa dalam berdiplomasi diri. Pola melayani dan mengabdi ini menjadi strategi perempuan untuk memiliki kuasa atas apa yang diinginkannya, karena dengan dua hal tersebut laki-laki sebagai suami akan luluh, sulit menolak, sehingga memberikan apa yang menjadi keinginan istri. Dalam istilah Jawa, posisi suami disebut sebagai posisi yang "dipangku", sebagai upaya perempuan untuk mengambil hatinya. Perempuan Jawa terbiasa dengan penderitaan atau siap menderita dalam segala situasi dan kondisi, sebagai contoh sudah menjadi kodratnya bahwa perempuan siap menderita selama kurang lebih sembilan bulan lebih sepuluh hari mengandung bayi. Dalam segala situasi apapun ketika mengandung, perempuan rela dengan ketidaknyamanan dan segala bentuk perubahan secara fisik yang dialaminya, namun tetap tulus berbakti kepada suami.

Perempuan menjadi penentu kebaikan suatu keluarga dengan sikap mental yang kuat dengan penderitaan, baik bagi suami maupun anak. Peran sebagai istri dan ibu di belakang layar menjadi tokoh sentral keluarga. Perempuan Jawa tidak tabu secara eksplisit berkeputusan, maka dengan sikap "penuh kelembutan" atau secara halus sehingga tidak menimbulkan ketidakselarasan adalah cara terbaik dalam menunjukkan sikap hormat kepada suami. Dengan sikap yang halus dan penuh simbol, perempuan Jawa memilih jalan bodho tapi pinter atau bodoh tapi cerdik, sebagai strategi untuk menang tanpa ngasorake atau menang tanpa merendahkan atau tanpa kekerasan, sehingga keputusan untuk mengubah suatu keadaan adalah hasil dari diplomasinya, namun yang terlihat dari orang lain bahwa hal tersebut merupakan hasil keputusan suami. Sikap memberi hormat tidak harus menunjuk pada otoritas yang sebenarnya, namun dalam keluarga Jawa otoritas tersebut terletak di tangan seorang ibu, namun yang menerima sikap hormat adalah bapak (Suseno, 2001: 68).

Serat Wulang Reh Jaya Lengkara memberikan ajaran bahwa sebagai pemimpin harus memiliki watak estri atau perempuan yang menang tanpa kekerasan. Serat tersebut mengajarkan laki-laki dalam perspektif paternalistik diposisikan sebagai pemimpin harus memiliki watak seperti yang dimiliki perempuan, yaitu mendapatkan kemenangan tanpa kekerasan. Sikap halus dan penuh simbol dengan memangku atau merangkul musuh merupakan bentuk perjuangan meraih kemenangan dalam kompetisi, dengan cara yang elegan tanpa merendahkan harga diri musuhnya. 
Sikap perempuan Jawa untuk selalu gemi atau hemat, wedi (takut), dan bekti ing laki (berbakti kepada suami) berlaku bagi perempuan dalam strata sosial manapun, meskipun dalam struktur sosial yang lebih tinggi dari suami. Menempatkan laki-laki di ranah publik sebagaimana dalam simbol area pendapa dan perempuan menempati rumah belakang atau dalem sebagai inti dari rumah Jawa, maka pola relasinya jelas, siapa dan berperan sebagai apa, dan di mana. Perempuan sebagai pendorong bagi suami untuk tampil di ranah publik. Perempuan sebagai "pemutus kebijakan" tanpa harus terlihat.

Serat atau naskah yang dibahas pada penelitian ini semuanya ditulis oleh laki-laki. Dalam lingkup budaya Jawa, mereka adalah laki-laki sebagai pemegang kuasa atau raja dan 'sastrawan' di area swapraja Vorstelanden, di antaranya Serat Wulang Estri Yasan Dalem Kanjeng Kusti Pangeran Adipati Pakualam II, Serat Wulang Reh Putri dalam bentuk tembang Kinanthi ditulis oleh Paku Buwana IX, Wulang Reh Putri dari Mangkunegaran, dan Serat Candrarini oleh Ranggawarsita. Tidak heran jika semua serat memberikan aturan bagi perempuan untuk tunduk terhadap laiklaki, sehingga terkesan bahwa posisi perempuan inferior. Pola relasi laki-laki dengan perempuan antara depan - belakang, atas - bawah.

Posisi perempuan terkesan inferior, namun kesemuanya memberikan sikap batin perempuan yang tulus dan ikhlas. Perannya selalu mengedepankan totalitas dengan wujud "sepi ing pamrih rame ing gawe" atau tidak memiliki pamrih, kehendak atau keinginan, tetapi rajin bekerja, baik dalam sebagai istri maupun ibu. Pemaknaan terhadap konco wingking tidak selamanya negatif, keberadaan orang di balik layar tidak selamanya berkonotasi negatif. Justru keberadaan konco wingking dalam budaya Jawa dimaknai sebagai sisi spiritual bagi suami dan keluarga. Maka peran konco wingking adalah penentu baik buruknya perilaku dan kebijakan suami sehingga harkat dan martabat keluarga selalu terjaga baik. Sebagaimana posisi egaliter dalam istilah garwo atau sigaraning nyowo, perempuan Jawa merupakan belahan jiwa menjadi satu kesatuan tim yang tidak terpisahkan dalam pola relasi suami dan istri. Satu entitas yang dua menjadi satu.

\section{Peran Perempuan dalam Pemerintahan Kadipaten Mangkunegaran}

Peran perempuan pada masa perjuangan raja-raja Mangkunegaran tidak kalah penting dalam membentuk sistem sosial di Kadipaten Mangkunegaran. Sejak masa perjuangan dan gerilya Raden Mas Said melawan kolonial. Raden Mas Said atau dikenal dengan nama Pangeran Samber Nyowo ditinggalkan ayahnya dalam pengasingan ke Sri Lanka dan ibunya Raden Ajeng Wulan meninggal sejak RM. Said usia dua tahun. Neneknya yang bernama Raden Ajeng Sumanarsa mengambil alih peran orang tua sehingga mengasuhnya di luar keraton dan terbiasa bergaul dengan kawulo alit. Raden Ajeng Sumanarsa menjadikannya kuat dan tangguh, serta mengetahui realita yang ada di lingkungan pergaulannya dengan para kawulo alit.

Perempuan berikutnya adalah Rubiyah, gadis Desa Matah, anak dari seorang ulama yang bernama Kyai Kasan Nuriman. Pertemuan antara Raden Mas Said dengan Rubiyah terjadi di Nglaroh, wilayah kekuasaan Raden Mas Said ketika membantu perjuangan Sunan Kuning melawan kolonial dan mendapatkan gelar Pangeran Prangwedana. Singkat cerita ketertarikan Raden Mas Said kepada Rubiyah membulatkan tekat melamarnya untuk dijadikan istrinya. Selanjutnya nama Rubiyah berganti dengan Raden Ayu Kusumopatahati (sekitar 1733-1788), hingga kemudian mendapatkan gelar Bendoro Raden Ayu Mangkoenagoro Sepuh.

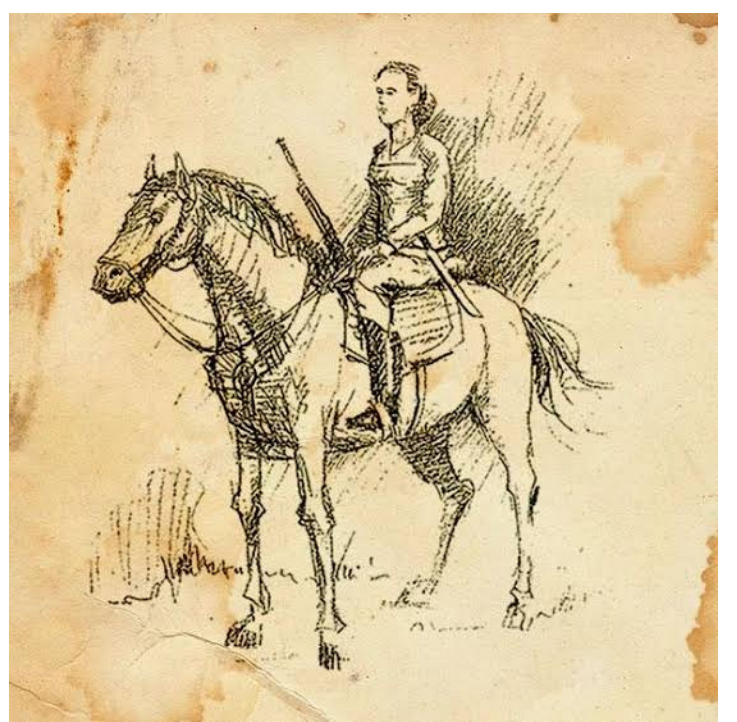


Gambar 1. Prajurit Estri masa Mangkunegara I (Sumber: Perempuan-Perempuan Perkasa di Jawa Abad XVIII-XIX, 2019).

Raden Mas Said selalu didampingi oleh neneknya Raden Ajeng Sumanarsa, kedua isterinya (Kanjeng Ratu Bendara dan Mas Ayu Matah Ati atau Raden Ayu Kusumopatahati), putera-puteranya dan pengikut setianya selama perjuangan dan berpindah-pindah, dalam jangka waktu yang panjang. Pengikut setianya di antaranya adalah prajurit estri berkuda yang berjumlah 144 orang. Mereka semua terlatih duduk di atas punggung kuda, naik turun pegunungan dan lembah, serta pandai dalam bertahan hidup. Bahkan Raden Mas Said atau Mangkunegara I juga mengangkat prajurit estri menjadi carik estri. Hal ini menunjukkan bahwa Mangkunegara I sangat memperhatikan pendidikan perempuan, agar tidak buta huruf. Tidak hanya kecakapan di bidang militer, namun juga pendidikan baca tulis.

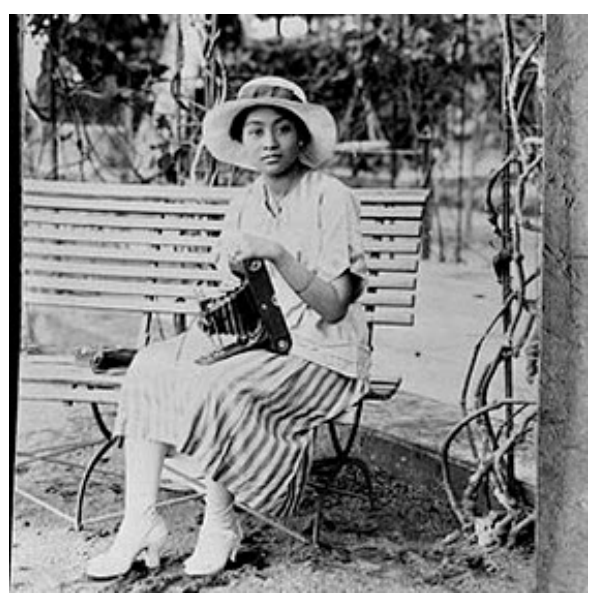

Gambar 2. Gusti Partini dengan gaya baju modern (Sumber: Reksopustoko Mangkunegaran)

Perempuan yang menonjol berikutnya di era Mangkunegara VII. Sebelum menikah dengan prameswari atau permaisuri, Mangkunegara VII memiliki garwa ampil atau selir yang bernama Mardewi. Mardewi melahirkan seorang putri bernama Bendoro Raden Ayu (BRAy) Partini sebelum diangkat menjadi raja Mangkunegara VII. BRAy Partini sebagai anak pertama atau putri tertua, yang diberikan kesempatan untuk berpikiran terbuka dan ikut aktif berorganisasi, hingga bertemu dengan Hoessein Djajadiningrat dan menikah. Hoessien Djajadiningrat adalah pribumi pertama yang meraih doktor di Universitas Leiden Belanda, hingga meraih gelar profesor pertama Indonesia dan menjadi "Bapak metodologi penelitian sejarah Indonesia". Peran BRAy. Partini sebagai perempuan Mangkunegaran yang berwawasan luas dan terbuka terbukti dengan kesuksesan yang diraih sang suami. Nama BRAy. Partini terabadikan menjadi nama taman Mangkunegaran, Partini Tuin dan Partinah Bosch (anak dari garwo ampil Mangkunegara VII yang bernama Bendoro Raden Setyawati).

Perempuan Mangkunegaran berikutnya adalah Nyi Bei Mardusari atau Nyi Tumenggung Mardusari, lahir di Wonogiri, 30 April 1909 sebagai seniwati serba bisa di lingkungan Mangkunegaran. Bidang kesenian yang dikuasainya adalah tari, sinden, batik, dan tata rias pengantin gaya Surakarta. Kemampuannya tersebut menjadikannya legenda yang masyur di lingkungan keraton bahkan hingga manca negara. Bahkan batik hasil karyanya menjadi panutan bagi pembatik-pembatik sekarang dari tingkat kerumitan dan kehalusan motif yang dibuatnya.

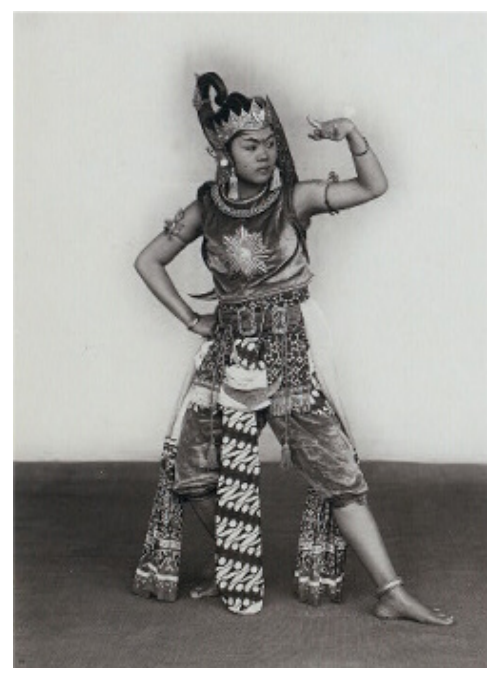

Gambar 3. Nyi Tumenggung Mardusari selir Mangkunegara VII (Sumber: Reksopustoko Mangkunegaran)

Perempuan Mangkunegara VII berikutnya adalah berposisi sebagai Garwo Padmil Prameswari atau permaisuri, yaitu Gusti Kanjeng Ratu Timoer merupakan adik istri Paku Buwono X. Dalam foto pernikahannya posisi berdiri di sisi kanan dari Mangkunegara VII. Sisi 
kanan merupakan tanda bahwa Gusti Kanjeng Ratu Timoer menduduki strata sosial lebih tinggi dari pada Mangkunegara VII. Tidak hanya foto pernikahan, setiap kali moment foto selalu terlihat di sisi kanan suaminya. Sebagai permaisuri Gusti Kanjeng Ratu Timoer ikut terlibat dalam pendidikan bagi para putri, dalam pengembangan seni dan budaya, pendidikan keterampilan perempuan, dan pendirian sekolah perempuan di lingkungan Pura Mangkunegaran.

Pernikahan Mangkunegara VII dengan Gusti Kanjeng Ratu Timoer melahirkan putri yang bernama Gusti Nurul Kamaril. Putrinya ini terkenal karena kecantikannya, pandai menari dan berwawasan luas. Gusti Nurul dididik oleh sang ibu dengan modern dan berwawasan terbuka, namun tidak meninggalkan jati diri sebagai putri Mangkunegaran yang pandai menari dan bergaul dalam skala internasional. Kecantikannya berhasil memikat para lelaki tokoh penting bangsa Indonesia, di antaranya Ir. Soekarno presiden pertama Republik Indonesia, dan Sri Sultan Hamengkubuwono IX. Namun karena Gusti Kanjeng Timur tidak menginginkan anaknya untuk dimadu, maka pilihan Gusti Nurul jatuh pada RM Soejarsoejarso Soerjosoerarso dan memutuskan keluar dari Pura Mangkunegaran dan tinggal di Jakarta.

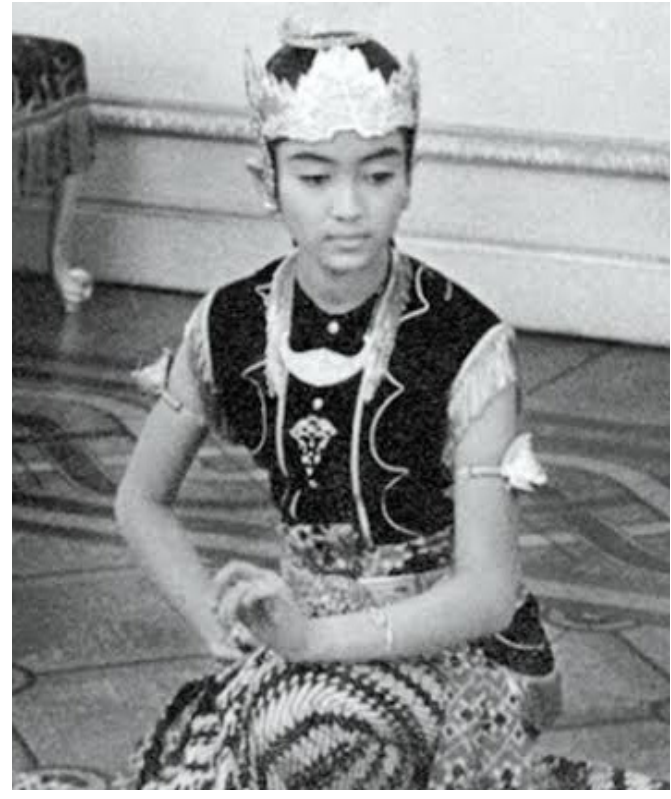

Gambar 5. Gusti Nurul Kamaril, putri Mangkunegara VII yang pandai menari (Sumber: Reksopustoko, 2019)
Kepiawaian Gusti Nurul dalam menari berhasil ditunjukkan dalam pentas tari untuk persembahan atau hadiah pernikahan bagi anak Ratu Wihelmina, yaitu Putri Juliana dengan Pangeran Bernhard. Tidak hanya Ratu Wihelmina yang menyaksikannya, namun termasuk para anggota kabinet di Amsterdam. Gusti Nurul berhasil mengundang kekaguman para tamu yang menghandiri acara pernikahan tersebut. Kekaguman tersebut karena budaya adi luhung yang dimiliki satu wilayah swapraja yang dikuasai oleh kolonial, namun mampu dan memiliki budaya yang luar biasa. Kekaguman tersebut menjadi bagian dari keberhasilan Mangkunegara VII dalam mengembangkan seni dan budaya dengan melibatkan para perempuan Mangkunegaran.

Periode Indonesia merdeka, perempuan Mangkunegaran mengambil peran sebagaimana karakter perempuan Jawa yang selalu hadir dengan kesantunan di forum-forum resmi dengan kebaya dan di bagian bawah menggunakan kain batik yang dililit dengan aturan tertentu dalam berpakaian dan mengenakan batik sesuai dengan motif yang dikenakan. Kesantunan berkebaya tersebut hadir dalam sosok Gusti Raden Ayu Sunituti. Di lingkungan Pura Mangkunegaran akrab dengan sebutan Gusti Putri.

Hj. Fatimah R.A. Siti Hartinah lebih dikenal dengan nama lbu Tien Soeharto merupakan cucu canggah dari Mangkunegara III, menjadi istri Soeharto, Presiden Indonesia ke-2. Tidak hanya permaisuri Mangkunegara VIII saja yang santun berkebaya, cucu canggah Mangkunegara III selalu hadir di acara kenegaraan mendampingi suami dengan berkebaya. Perannya selama kepemimpinan Soeharto selama 32 tahun tidak bisa dipungkiri sebagai perempuan Jawa yang secara sadar sebagai istri dan ibu perawat budaya dan menegakkan nilai-nilai tradisional Jawa, sehingga harkat dan martabat keluarga terjaga dan dijunjung tinggi. Prinsip rukun dan hormat dalam masyarakat Jawa tercapai sehingga keselarasan dan harmoni tercapai. 


\section{KESIMPULAN}

Bahasa Jawa memiliki padanan kata untuk menyebut perempuan, khusus bagi yang sudah menikah dan berposisi sebagai istri. Padanan kata tersebut wadon, wanitå, estri, dan putri. Perempuan bermakna makhluk yang mulia atau berkemampuan, sedangkan tiga padanan kata perempuan wadon, wanitå, estri bermakna bahwa perempuan selama hidup mengabdi kepada laki-laki (suami), berani diatur dan mengatur, dan berperan sebagai pendorong yang memberi dukungan, dan semangat bagi suami. Khusus makna putri merupakan akronim yang bermakna bahwa perempuan harus memutuskan tiga perkara sebagai wadon, wanitå, estri. Perempuan dalam budaya Jawa juga disebut sebagai nareswari, yang bermakna perempuan sebagai penerus keturunan. Nareswari merupakan kodrat yang tidak dapat dipertukarkan dengan laki-laki, sehingga bobot, bébéd, bibit seorang perempuan calon istri menjadi perhatian khusus. Perempuan dengan kodratnya tersebut bermakna bahwa perempuan sebagai pembentuk peradaban.

Prinsip rukun dan hormat dalam budaya Jawa menempatkan pribadi menjadi bagian dari hidup orang lain yang berperan untuk menjaga keselarasan antara makrokosmos dengan mikrokosmos. Perempuan berperan dalam menjaga keselarasan tersebut, agar tercapai harmoni. Peran perempuan tersebut terkandung dalam beberapa serat. Serat Wulangreh mengajarkan manusia, baik laki-laki maupun perempuan Jawa, bahwa sikap batiniah menjadi dasar berpijak dalam berkehidupan. Serat Candrarini mengajarkan kepada perempuan agar terus berdoa agar mendapatkan anugerah dari Tuhan dan lima kaarakter perempuan istri Arjuna yang karakternya saling melengkapi. Prinsip hormat dalam budaya Jawa menempatkan orang lain sehormat-hormatnya, layaknya memperlakukan diri sendiri, hingga tercipta prinsip rukun.

Serat Wulangreh, Serat Wulang Estri, Serat Candrarini, Serat Yadya Susila, Serat Wulang Jayalengkara, dan Serat Centhini mengajarkan kepada perempuan dalam berumahtangga dan mengabdi sebaik-baiknya kepada suami. Perempuan Jawa dengan istilah sebgai konco wingking dan garwo, merupakan pembagian peran dan berbagi tugas dalam berumah tangga. Kepatuhan dan kesantunan perempuan Jawa sebagai bentuk ekpresi bahwa strategi berdiplomasi untuk mendapatkan keinginannya tidak dengan kekerasan. Meski terkesan inferior dengan istilah konco wingking, namun sejatinya perempuan Jawa sadar, bahwa meskipun tidak hadir di wilayah publik namun sejatinya perempuan sebagai penentu kebijakan keluarga, tanpa harus terlihat. Perempuan sebagai garwo atau sigaraning nyowo menempatkan perempuan sebagai bagian dari dua menjadi satu entitas.

Raja-raja (Adipati) Mangkunegara menempatkan perempuan sebagai bagian dari upaya memperjuangkan hak dan kehendaknya sebagai pemimpin yang mampu merangkul siapapun. Raja-raja (Adipati) dan generasi penerus Mangkunegaran menempatkan perempuan, baik permaisuri maupun selir sebagai konco wingking dalam konotasi positif, sekaligus sebagai garwo. Konco wingking dan garwo meskipun terkesan inferior, namun sebenarnya sebagai bentuk penghargaan, penghormatan sekaligus peran sebagai entitas yang satu. Perjuangan dan kebijakan raja-raja Mangkunegaran yang melibatkan perempuan sebagai bentuk implementasi sistem budaya yang adaptif, baik dalam wilayah domestik maupun pendidikan formal atau di ranah publik bahkan semacam diplomasi budaya.

\section{DAFTAR PUSTAKA}

Carey, Peter \& Houben, Vincent. 2019. Perempuan-Perempuan Perkasa di Jawa Abad XVIII-XIX. Jakarta: PT. Gramedia.

Darweni. 1994. Wulang Reh Putri Karya PB IV (Transkripsi Naskah), Solo: Reksopustoko Istana Mangkunegaran.

Dharsono, Soni Kartika. 2007. Estetika, Bandung: Rekayasa Sains Bandung, 120-121.

Endraswara, Suwardi. 2016. Berpikir Positif Orang Jawa, Penerbit: Narasi, Yogyakarta, 3,5 . 
Frick, Heinz. 1997. Pola Struktural dan Teknik Bangunan di Indonesia, Jogyakarta: Penerbit Kanisius, 85

Handayani, Christina \& Novianto, Ardhian. 2004. Kuasa Wanita Jawa, LKiS Yogyakarta, Yogyakarta, 120.

Koentjaraningrat, 1990. Pengantar IImu Antropologi, PT Rineka Cipta, Jakarta, 181-185, 224.

Metz, Th. M., 1939. Mangkunegaran Analisis Sebuah Kerajaan (MN 832), NV Nijgh \& Van Ditmar, Rotterdam,1, 86, 91, 107.

Metz, Th. M., 1939. Seorang Raja Jawa (MN 841), De Indische Gids, Juli 1939 No.7.

Rinkes, D.A. 1978. Mangkunegaran (MN 142) dari De Mangkunagaran door, 1-6.

Singgih, Roswitha Pamoentjak. 1986. Partini: Tulisan Kehidupan Seorang Putri Mangkunegaran. Jakarta: Penerbit Djambatan.

Soedarsono, RM. \& Murniatmo, Gatut (editor). 1986. Nilai Anak dan Wanita dalam Masyarakat Jawa, Direktorat Jenderal Kebudayaan, Departemen Pendidikan dan Kebudayaan.

Soeratman, Darsiti. 1989. Kehidupan Dunia Keraton Surakarta 1830-1939, Penerbit Yayasan Penerbitan Tamansiswa TS PRESS, Yogyakarta, 50.

Soemarsono, Yuliastuti dkk. 2011. Lembar Kenangan Gusti Nurul, Penerbit HKMNS- Himpunan Kerabat Mangkunagaran Suryasumirat.

Suseno, Franz Magnis. 1996. Etika Jawa: Sebuah Analisa Falsafi tentang Kebijaksanaan Hidup Jawa, PT. Gramedia Pustaka Utama, Jakarta, 39-81.

Trunasurata, Suyatno. 1995. Serat Candrarini Tuwin Rarakenya: Piwulang Dalem Ingkang Sinuwun PB. IX, Surakarta: Reksopustoko Mangkunegaran. 